\title{
Changes in Enzyme Activity and Components in the Extract of Oyster during Fermentation
}

\author{
Ching-Yu Tsao*1 and Fumio Nagayama*2 \\ (Received January 14, 1992)
}

\begin{abstract}
With $(15 \%)$ and without $\mathrm{NaCl}$, the $\mathrm{pH}$ value of oyster paste dropped to 5 and below 4 respectively, throughout fermentation. The activities of enzymes except amylase in $15 \% \mathrm{NaCl}$ were completely or partially inhibited during fermentation.

The total amount of free amino acids of oyster was $1,692 \mathrm{mg} / 100 \mathrm{~g}$, and the major free amino acids were Tau, Glu, Pro, Gly, Ala, and Asp. The six amino acids accounted for $70 \%$ of the total free amino acid. About $35 \mathrm{mg} / 100 \mathrm{~g}$ of $\beta$-Ala was detected. After fermentation, the maximum amino acid content in the extract with and without sodium chloride reached 2,225 and $3,103 \mathrm{mg} / 100$ g, respectively.

The major nucleosides and their derivatives in oyster were inosine, guanosine, and hypoxanthine. Small quantities of AMP, ADP, and ATP were observed, but IMP was not detected. After four days, nucleotide could not be detected in the presence of salt.
\end{abstract}

Since the extractive constituents of oyster were first observed in $1929,{ }^{1}$ it has been shown that the components vary according to species, ${ }^{2-5}$ ) season, ${ }^{-10)}$ and region. ${ }^{11}$ It was also noticed in the last three decades that the taste is closely related to the extractive components. Now, about 60 species of fish and shell-fish have been investigated in terms of extracts and their nitrogenous component profiles. ${ }^{2}{ }^{12}$ The relationship between each nitrogenous component and the taste has also been clarified by many workers. ${ }^{13-14}$ )

Because of its high level of nutrients such as glycogen, sarcoplasmic protein etc., the oyster is called "Sea Milk" and is extensively utilized all over the world. In addition, the oyster, having a high level of taurine, has been recognized as a healthy food for humans. ${ }^{13)}$ Moreover, it has a special taste and flavor which are different from those of other marine crustaceans and bivalvia, such as lobster, crab, shrimp, scallop, etc. The utilization of the extracts as food additives has been actively developed in Japan. ${ }^{1 s-1 a)}$

Although the profiles of non-nitrogenous and nitrogenous components of oyster have been investigated by some workers, ${ }^{1-10,17,18)}$ the changes of these components and enzyme activities during fermentation have not yet been noticed. In this paper, the relationship between changes in ex- tractive components and enzyme activities during fermentation is discussed.

\section{Materials and Methods}

\section{Materials}

Frozen oysters Crassostrea gigas were purchased and transported to the laboratory, and then stored at $-35^{\circ} \mathrm{C}$ until use.

\section{Fermentation Conditions}

Five kilograms of frozen shucked oyster were homogenized and incubated at $25^{\circ} \mathrm{C}$ for 0,1 , $2,4,7$, and 14 days in the presence or absence of $15 \% \mathrm{NaCl}$.

\section{Crude Enzyme Extract}

From $5 \mathrm{~g}$ of each sample (about $500 \mathrm{~g}$ ), the crude enzyme was extracted with three volumes of cold $\left(5^{\circ} \mathrm{C}\right) 10 \mathrm{~mm}$ Tris- $\mathrm{HCl}$ buffer, $\mathrm{pH} 8$, and centrifuged at $10,000 \times \mathrm{g}$ for $30 \mathrm{~min}$. The supernatant was treated with solid ammonium sulfate; and then the precipitates $(30-70 \%)$ were collected and dissolved in a minimum volume of the same buffer solution. Then, the residual ammonium sulfate was removed by dialysis against the same buffer overnight. The crude enzyme solution was centrifuged again at $36,000 \times \mathrm{g}$ for $30 \mathrm{~min}$ to

*1 Department of Marine Food Science, National Taiwan Ocean University, Peining Rd., Keelung 20224, Taiwan, R.O.C，(曹 鍁玉：国立台湾海洋大学水蓙食品科学系).

*2 Department of Food Science and Technology, Tokyo University of Fisheries, Konan, Minato, Tokyo 108, Japan (永山文男: 東京水偟大学食品生産学科), 
remove undissolved proteins.

\section{Enzyme Activities}

The enzyme activities of trypsin, chymotrypsin, carboxypeptidase A, amylases, nucleotidase, glucose 6-phosphate dehydrogenase (Glc-6-P DH), alkaline phosphatase, lactate dehydrogenase (LDH), lipase, and phospholipase were determined using the methods described by Kunitz, ${ }^{19)}$ Rick, ${ }^{20}$ Walsh, ${ }^{21)}$ Bergmeyer et al., ${ }^{22)}$ Appel, ${ }^{23)}$ Yoshinaka et al., ${ }^{24)}$ Bernfeld, ${ }^{26)}$ Heppel and Hilmoe, ${ }^{28)}$ Noltmann et al.,87) Bergmeyer et al., ${ }^{\text {,8) }}$ and Searcy et al., ${ }^{997}$ respectively.

\section{Preparation of Extract}

According to Suyama's method, ${ }^{30)}$ the extract was prepared with $6 \%$ perchloric acid. Using the $o$-phthalaldehyde method, ${ }^{31}$ the compositions of free amino acids and dipeptides were determined by high-performance liquid chromatography (HPLC), developed by Jasco Co. Ltd., with Finepak series AApak $\mathrm{Li}^{+}$column. The nucleotides were also determined by HPLC with Biofine IEC-DEAE column.

\section{Protein}

The micro-Kjeldahl method was used to determine the crude protein of each sample. The Lowry method ${ }^{32}$ ) was employed to measure the enzyme protein concentration, using crystalline bovine serum albumin as standard.

\section{Volatile Basic Nitrogen}

The volatile basic nitrogen (VB-N) of each sample was determined by Conway's diffusion method, as described by Cobb III et al..$^{337}$

\section{Glycogen and Its Metabolites}

Glycogen and its metabolites, glucose, glucose 1-phosphat (Glc-1-P), Glc-6-P, fructose 6-phosphate (Frc-6-P), fructose 1-phosphate (Frc-1-P), fructose 1, 6-bisphosphate (FBP), and lactic acid, were measured enzymatically with the methods described by Bergmeyer et $a l_{.}{ }^{\mathrm{B})}$

\section{Inorganic Phosphorus}

According to the method described by Allen, ${ }^{34}$ the inorganic phosphate in the sample solution was measured colorimetrically at $640 \mathrm{~nm}$.

\section{Results and Discussion}

Changes in Content of Glycogen and Its Metabolites during Fermentation

The result of analyzing glycogen and its metabolites of oyster during fermentation is shown in Fig. 1. After 14-day fermentation with $15 \%$ salt, the glycogen decreased from 24.6 to $0 \mathrm{mg} / \mathrm{g}$, and the quantity of Glc-1-P, Glc-6-P, Fec-6-P, and FBP, were also found to have decreased. The quantity of reducing sugar and inorganic phosphate increased from $8.8 \mathrm{mg} / \mathrm{g}$ and $14.9 \mathrm{mmol}$ to $32.9 \mathrm{mg} / \mathrm{g}$ and $24.8 \mathrm{mmol}$, respectively. In addition, the quantity of volatile basic nitrogen also increased from 16.7 to $34.7 \mathrm{mg} / 100 \mathrm{~g}$ and the quantity of lactic acid reached $4.8 \mathrm{mg} / \mathrm{g}$. Consequently, the $\mathrm{pH}$ value gradually decreased from 5.9 to 5.1 .

On the other hand, the glycogen remained at $9.8 \mathrm{mg} / \mathrm{g}$ in the sample without salt. The quantity of hexose phosphate such as Glc-6-P, Glc-1-P, Frc-6-P, and FBP also gradually decreased during fermentation. About 7 days for Glc-6-P and 4 days for the others were required for complete hydrolysis. After 4-day fermentation, lactic acid reached the maximum level, $23.3 \mathrm{mg} / \mathrm{g}$, and VB-N also reached $93 \mathrm{mg} / 100 \mathrm{~g}$. Consequently, the $\mathrm{pH}$ value dropped to 3.5 , the minimum value. The VB-N continued to increase and lactic acid showed a decreasing tendency throughout further fermentation. During fermentation, there was no undesirable odor. This phenomenon might come from the reason that generated odorants such as ammonium and amines were neutralized by lactic acid.

There have been many reports to describe the glycogen in fish and shellfish. ${ }^{2-3,35-38)}$ However, all of these have involved themselves in discussing its content or degradation during storage. With $(15 \%)$ or without $\mathrm{NaCl}$, the change in glycogen showed a rapid decrease, but no significant difference between the two on the first day of fermentation; the former decreased to zero and the latter showed no notable change throughout fermentation. These results will be explained in the next section by the fact that the amylase activity was completely inhibited in the absence of $\mathrm{NaCl}$ during further fermentation. Sakaguchi and Murata ${ }^{10}$ suggested that the glycogen could be related to the palatable taste of oyster because it accumulates glycogen in winter when the oyster is also at its most delicious taste. On the other hand, Ichikawa ${ }^{18)}$ reported that oyster 


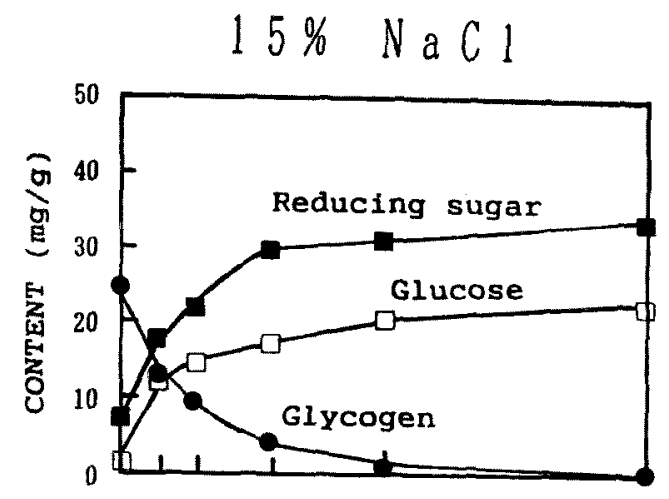

$0 \% \quad \mathrm{NaCl}$
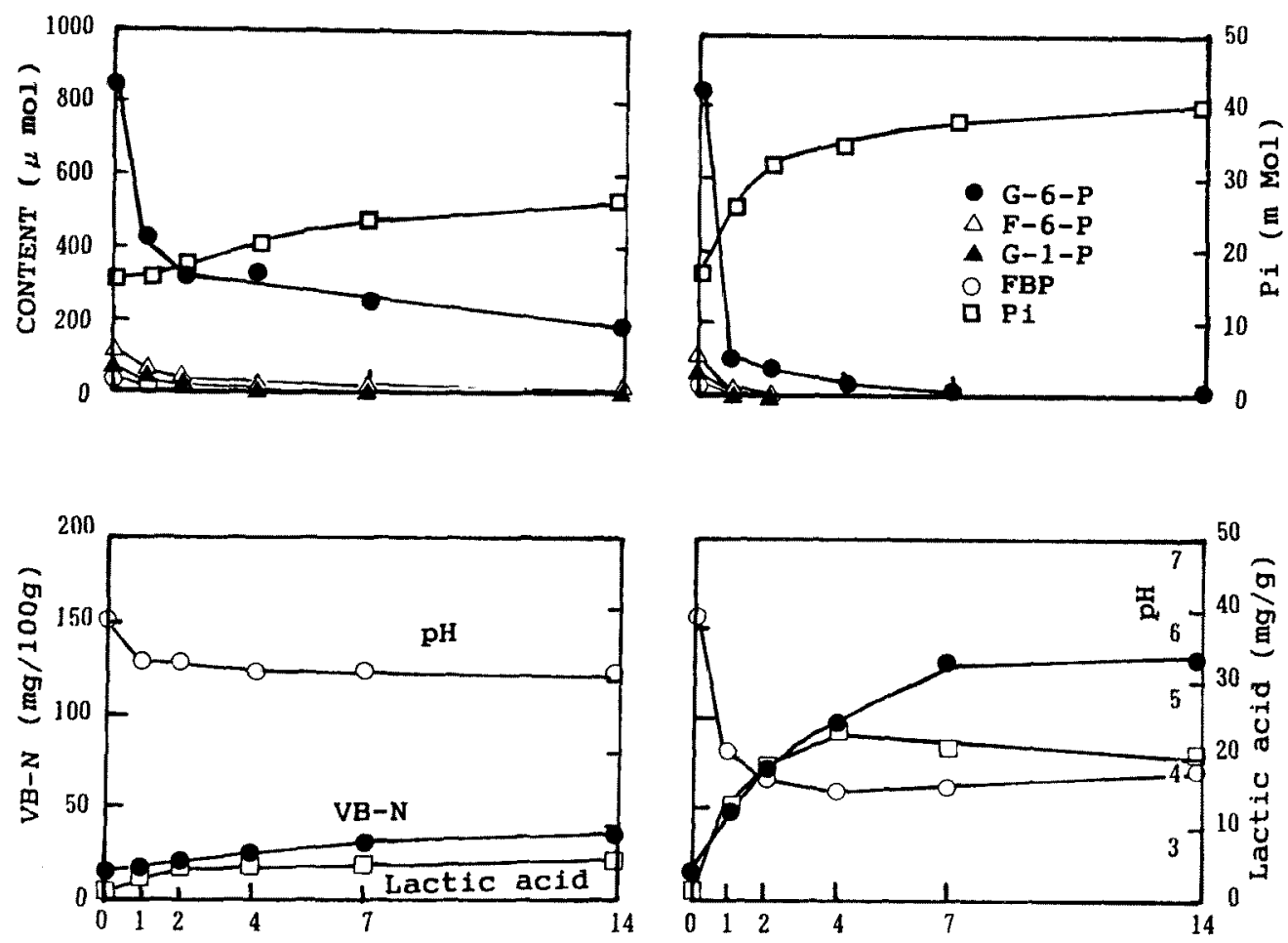

\section{INCUBATION TIME ( DAY)}

Fig. 1. Changes in the components of oyster during fermentation.

Upper: glycogen -o, reducing sugar $\square-\square$, glucose $\square-\square$.

Middle: G-6-P - F-6-P $\triangle-\Delta$, G-1-P $\triangle-\Delta$, FBP $O-0, P i \square-\square$.

Bottom: Volatile basic nitrogen -0 , lactic acid $\square-\square, \mathrm{pH} \bigcirc-\mathrm{O}$. 


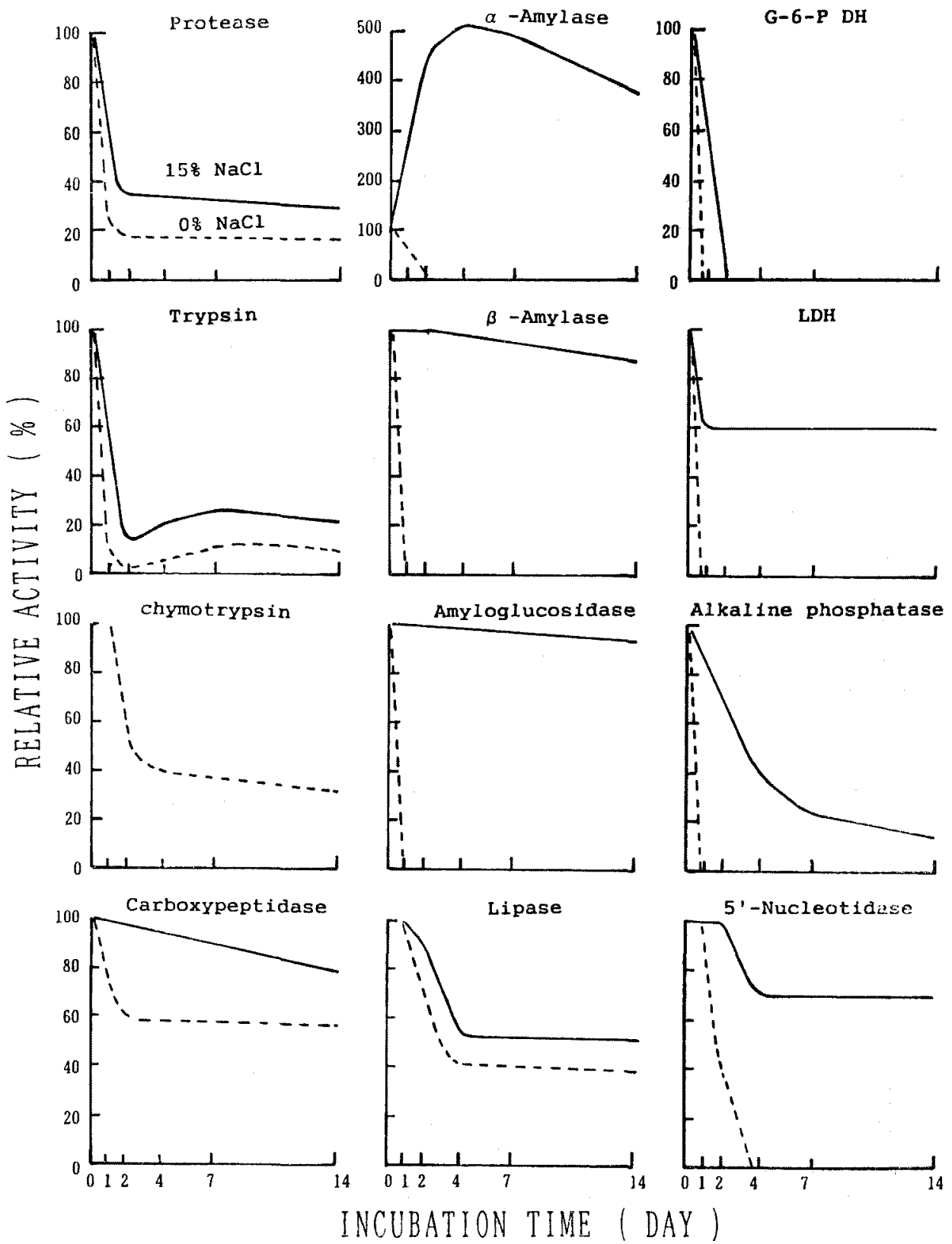

Fig. 2. Changes in the enzymes activities of oyster during fermentation. ,$- 15 \% \mathrm{NaCl} ;-\cdots, 0 \% \mathrm{NaCl}$

sauce of high quality could be prepared by natural fermentation with $15 \% \mathrm{NaCl}$. A high level of reducing sugar including glucose was found remaining in the hydrolysate after two weeks" fermentation with $15 \% \mathrm{NaCl}$ in this study. So, on the basis of these arguments, it was suggested that sweetness by reducing suger (glucose) which accumulated in the hydrolysate may contribute to the palatable taste of oyster sauce.

The contents of Glc-6-P were higher than those of any other hexose phosphate in the oyster (Fig. 1). It was reported that the amount of Glc-6-P 
Table 1. The enzyme activity of oyster before fermentation

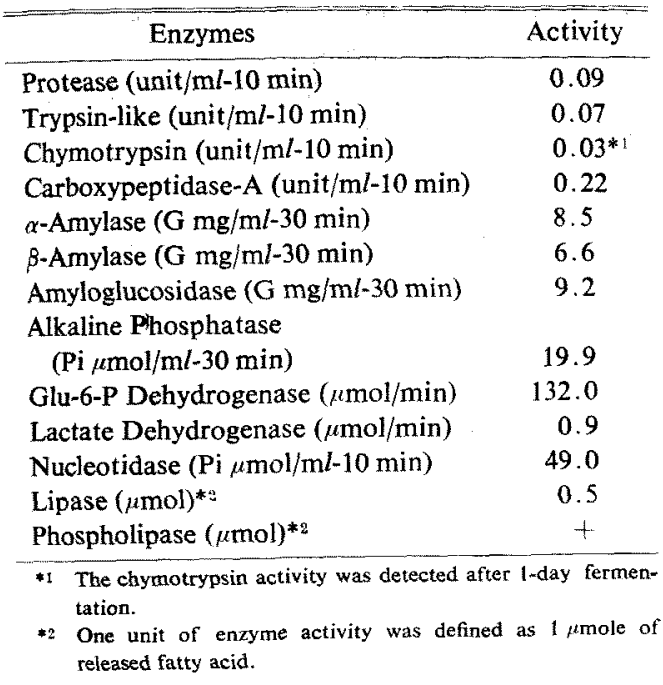

was highest in all glycolytic metabolites in kuruma prawn, $^{38}$ ) scallop adductor, ${ }^{38)}$ and seabass ${ }^{37}$ ) muscles. Glc-6-P plays an important role in Maillard reaction, as is well known, ${ }^{38)}$ and Nagayama $^{40)}$ suggested that most acids inhibit browning by their pH-lowering action. Therefore, although the remaining high level of Glc-6-P in hydrolysates could induce a brown reaction, the extremely high level of lactic acid might prevent it from occurring.

Changes of Enzyme Activities during Fermentation The activities of enzymes existing in the oyster are determined during fermentation. The results are shown in Table 1. The activities of proteolytic enzymes, protease, trypsin-like, and carboxypeptidase $A$ were $0.09,0.07$, and 0.22 units $/ \mathrm{m} /$ -
$10 \mathrm{~min}$, respectively; the activities of amylolytic enzymes, $\alpha$ - and $\beta$-amylase, and amyloglucosidase were $8.5,6.6$, and $9.2 \mathrm{G} \mathrm{mg} / \mathrm{m} /-30 \mathrm{~min}$, respectively. The activity of Glc-6-P DH was $132 \mu \mathrm{mol} /$ min. Alkaline phosphatase and nucleotidase activity were $19.9 \mathrm{Pi} \mu \mathrm{mol} / \mathrm{ml} l-30 \mathrm{~min}$ and 49 $\mathrm{Pi} \mu \mathrm{mol} / \mathrm{ml}-10 \mathrm{~min}$, respectively. LDH activity was $0.9 \mu \mathrm{mol} / \mathrm{min}$. Lipase activity was 0.5 $\mu$ mole of released fatty acid. Chymotrypsin and phospholipase showed very weak activity before fermentation.

During incubation at $25^{\circ} \mathrm{C}$ with $(15 \%)$ and without $\mathrm{NaCl}$, the changes of enzyme activities were traced (Fig, 2). The protease was found to lose $70-80 \%$ of its initial hydrolytic activity within 2 days, but it kept this level during further fermentation. Trypsin-like protease was found to lose about $90 \%$ of its activity and then kept its level throughout fermentation. The activity of carboxypeptidase A gradually decreased to $75 \%$ of its initial value after 14 days' fermentation in the presence of $\mathrm{NaCl}$. In the absence of $\mathrm{NaCl}$, however, the activity decreased to about $60 \%$ during the initial 2 days' fermentation and showed almost no change after that. The activity of chymotrypsin could hardly be detected throughout fermentation with $15 \% \mathrm{NaCl}$. On the other hand, it was detected after one day's fermentation without salt, and was taken as $100 \%$, but then decreased during further fermentation. Therefore, it was considered that this enzyme might exist in the form of apoenzyme in the oyster.

In addition, the amylolytic enzymes $\alpha$ - and $\beta$-amylase and amyloglucosidase were found to lose their activities quickly during fermentation without salt. The enzyme protein was probably denatured and lost its hydrolytic ability due to a

Table 2. Changes in content of nucleotide and its derivatives of oyster during fermentation with $15 \%$ and without $\mathrm{NaCl}$

(mg/100g meat)

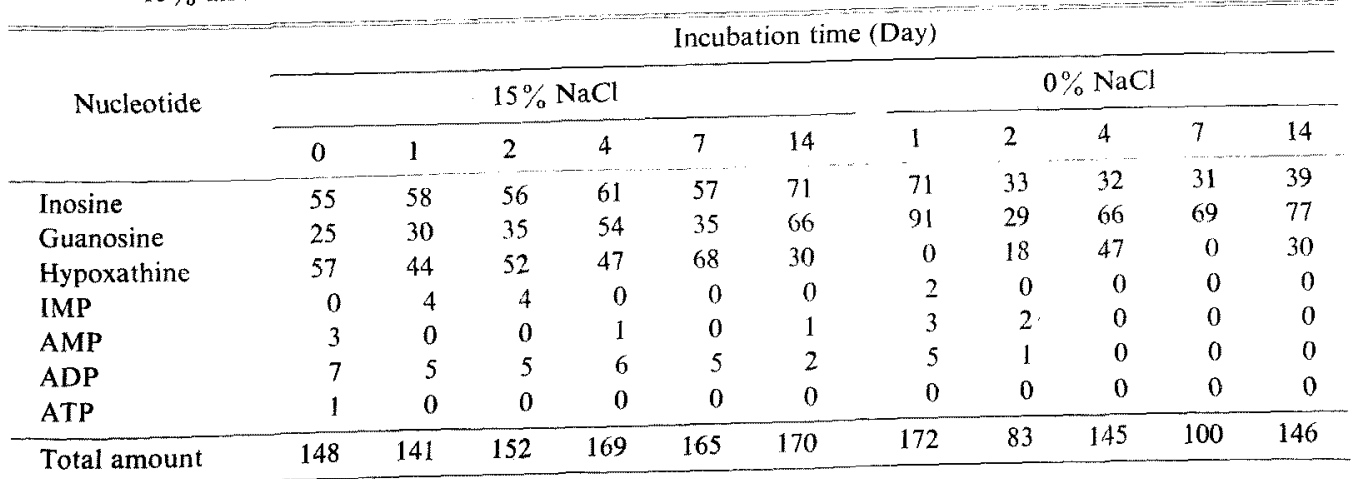


low $\mathrm{pH}$ condition over a long period. In contrast, with $15 \%$ salt, the activites of $\alpha$-amylase and amyloglucosidase did not show any significant change. However, the activity of $\alpha$-amylase increased sharply within 4 days' fermentation. This phenomenon might be explained by the fact that the halophilic microorganism secreted the same as this enzyme.

During fermentation without salt, the activities of Glc-6-P DH, alkaline phosphatase, $\mathrm{LDH}$, and nucleotidase decreased quickly to zero after 1 day or 4 days, and the lipase activity gradually fell to $40 \%$. In contrast, during fermentation with $15 \%$ $\mathrm{NaCl}$, the activities of Glc-6-P decreased sharply to zero within 2 days, but activities of other enzymes keeping approximately 60,70 , or $50 \%$, and gradually fell to $15 \%$ throughout it. The activity of phospholipase showed no changes in

Table 3. Changes in free amino acids contents of oyster during fermentation at $25^{\circ} \mathrm{C}$ with $15 \%$ $\mathrm{NaCl}$

(mg/100 g meat)

\begin{tabular}{|c|c|c|c|c|c|c|}
\hline \multirow{2}{*}{ Amino acid } & \multicolumn{6}{|c|}{ Incubation time (Day) } \\
\hline & 0 & 1 & 2 & 4 & 7 & 14 \\
\hline Nitrogen & 271 & 280 & 295 & 344 & 346 & 356 \\
\hline P-Ser & 8 & 8 & 10 & 11 & 11 & 13 \\
\hline Tau & 614 & 607 & 574 & 586 & 565 & 534 \\
\hline$o$-PEA & 8 & 5 & 6 & 6 & 6 & 9 \\
\hline Asp & 72 & 82 & 91 & 122 & 117 & 141 \\
\hline Hyp & 57 & 81 & 86 & 134 & 120 & 127 \\
\hline Thr & 51 & 59 & 68 & 83 & 86 & 92 \\
\hline Ser & 28 & 34 & 43 & 56 & 60 & 66 \\
\hline Asn & 0 & 0 & 0 & 0 & 0 & 0 \\
\hline Glu & 168 & 168 & 187 & 221 & 223 & 233 \\
\hline Gln & 0 & 0 & 0 & 0 & 0 & 0 \\
\hline Sar & 0 & 0 & 0 & 0 & 0 & 0 \\
\hline$\alpha-\mathrm{AAA}$ & 19 & 21 & 20 & 22 & 19 & 18 \\
\hline Pro & 137 & 26 & 98 & 109 & 58 & 34 \\
\hline Gly & 78 & 73 & 80 & 91 & 92 & 99 \\
\hline Ala & 149 & 158 & 174 & 198 & 192 & 211 \\
\hline $\mathrm{Cit}$ & 0 & 0 & 0 & 0 & 0 & 0 \\
\hline$\alpha-\mathrm{ABA}$ & 9 & 0 & 9 & 7 & 10 & 5 \\
\hline Val & 34 & 49 & 68 & 86 & 99 & 108 \\
\hline Cys & 0 & 0 & 0 & 0 & 0 & 0 \\
\hline Met & 0 & 0 & 0 & 0 & 0 & 0 \\
\hline Cyt & 0 & 0 & 0 & 0 & 0 & 0 \\
\hline Ile & 16 & 21 & 27 & 34 & 38 & 42 \\
\hline Leu & 23 & 34 & 42 & 51 & 55 & 60 \\
\hline Tyr & 16 & 22 & 26 & 31 & 34 & 35 \\
\hline Phe & 15 & 24 & 30 & 37 & 40 & 43 \\
\hline$\beta$-Ala & 35 & 35 & 34 & 36 & 34 & 36 \\
\hline$\beta-\mathrm{ABA}$ & 0 & 0 & 0 & 0 & 0 & 0 \\
\hline$\gamma-\mathrm{ABA}$ & 0 & 0 & 0 & 0 & 0 & 0 \\
\hline EA & 27 & 36 & 21 & 26 & 38 & 26 \\
\hline $\mathrm{NH}_{3}$ & 24 & 29 & 20 & 23 & 27 & 26 \\
\hline Orn & 9 & 15 & 14 & 11 & 10 & 10 \\
\hline Lys & 36 & 82 & 40 & 88 & 107 & 122 \\
\hline 1-MeHis & 0 & 0 & 0 & 0 & 0 & 0 \\
\hline His & 15 & 19 & 17 & 20 & 20 & 21 \\
\hline 3-MeHis & 0 & 10 & 0 & 10 & 0 & 0 \\
\hline Ans & 0 & 0 & 11 & 0 & 25 & 34 \\
\hline Car & 0 & 0 & 0 & 0 & 0 & 0 \\
\hline Arg & 44 & 52 & 50 & 51 & 76 & 80 \\
\hline Total amounts & 1,692 & 1,750 & 1,846 & 2,150 & 2,162 & 2,225 \\
\hline
\end{tabular}


this study.

\section{Changes in Nucleotides during Fermentation}

Nucleotides and their derivatives in oyster were analyzed during fermentation with $(15 \%)$ and without $\mathrm{NaCl}$. The results are shown in Table 2. The total nucleotides were $148 \mathrm{mg} / 100 \mathrm{~g}$ and no significant change in content was observed during fermentation. The major nucleotides and their derivatives of oyster are inosine, guanosine, and hypoxanthine, while small quantities of AMP, ADP, and ATP were also observed, though IMP could not be detected. Although adenine nucleotides were found in large quantity in living crustaceans and mollusks, the taste enhancers AMP and IMP were easily degraded in postharvest storage $^{2)}$ and struggling fish. ${ }^{30}$ Therefore, after 4-day fermentation without salt, all nucleotides

Table 4. Changes in free amino acids contents of oyster during fermentation at $25^{\circ} \mathrm{C}$ without sodium chloride

(mg/100 g meat)

\begin{tabular}{|c|c|c|c|c|c|c|}
\hline \multirow{2}{*}{ Amino acid } & \multicolumn{6}{|c|}{ Incubation time (Day) } \\
\hline & 0 & 1 & 2 & 4 & 7 & 14 \\
\hline Nitrogen & 271 & 337 & 394 & 427 & 496 & 457 \\
\hline P-Ser & 8 & 11 & 12 & 13 & 15 & 14 \\
\hline Tau & 614 & 550 & 557 & 536 & 619 & 607 \\
\hline$o$-PEA & 8 & 8 & 6 & 10 & 11 & 10 \\
\hline Asp & 72 & 27 & 99 & 135 & 179 & 168 \\
\hline Hyp & 57 & 114 & 156 & 138 & 156 & 150 \\
\hline Thr & 51 & 81 & 99 & 113 & 144 & 131 \\
\hline Ser & 28 & 36 & 40 & 60 & 84 & 53 \\
\hline Asn & 0 & 0 & 0 & 0 & 0 & 0 \\
\hline Glu & 168 & 221 & 256 & 299 & 355 & 270 \\
\hline Gln & 0 & 0 & 0 & 0 & 0 & 0 \\
\hline Sar & 0 & 0 & 0 & 0 & 0 & 0 \\
\hline$\alpha-\mathrm{AAA}$ & 19 & 22 & 20 & 15 & 16 & 16 \\
\hline Pro & 137 & 113 & 111 & 125 & 77 & 75 \\
\hline Gly & 78 & 109 & 106 & 105 & 141 & 128 \\
\hline Ala & 149 & 264 & 270 & 283 & 341 & 306 \\
\hline Cit & 0 & 0 & 0 & 0 & 0 & 0 \\
\hline$\alpha-\mathbf{A B A}$ & 9 & 6 & 8 & 3 & 3 & 9 \\
\hline Val & 34 & 85 & 123 & 151 & 192 & 175 \\
\hline Cys & 0 & 0 & 0 & 0 & 0 & 0 \\
\hline Met & 0 & 0 & 6 & 11 & 12 & 10 \\
\hline Cyt & 0 & 0 & 0 & 0 & 0 & 0 \\
\hline Ile & 16 & 34 & 56 & 64 & 75 & 64 \\
\hline Leu & 23 & 55 & 86 & 97 & 111 & 94 \\
\hline Tyr & 16 & 34 & 42 & 48 & 43 & 33 \\
\hline Phe & 15 & 43 & 67 & 73 & 84 & 74 \\
\hline$\beta-A l a$ & 35 & 36 & 35 & 34 & 37 & 36 \\
\hline$\beta * \mathrm{ABA}$ & 0 & 0 & 0 & 0 & 0 & 0 \\
\hline$\gamma-\mathrm{ABA}$ & 0 & 7 & 11 & 9 & 16 & 16 \\
\hline $\mathrm{EA}$ & 27 & 39 & 14 & 12 & 17 & 26 \\
\hline $\mathrm{NH}_{3}$ & 24 & 29 & 29 & 29 & 37 & 51 \\
\hline Orn & 9 & 33 & 25 & 16 & 26 & 40 \\
\hline Lys & 36 & 53 & 109 & 118 & 172 & 189 \\
\hline 1-MeHis & 0 & 0 & 0 & 0 & 0 & 0 \\
\hline His & 15 & 19 & 20 & 21 & 27 & 31 \\
\hline 3-MeHis & 0 & 0 & 9 & 10 & 6 & 9 \\
\hline Ans & 0 & 43 & 20 & 33 & 0 & 11 \\
\hline $\mathrm{Car}$ & 0 & 0 & 0 & 0 & 0 & 0 \\
\hline Arg & 44 & 36 & 71 & 105 & 107 & 59 \\
\hline Total amounts & 1,692 & 2,108 & 2,463 & 2,666 & 3,103 & 2,855 \\
\hline
\end{tabular}


entirely degraded into their derivatives.

\section{Changes in Free Amino Acids and Dipeptides during Fermentation}

The changes in the contents of free amino acids and dipeptides of oyster during fermentation were investigated. As shown in Tables 3 and 4 , the total amount of free amino acids of the initial stage was $1,672 \mathrm{mg} / 100 \mathrm{~g}$ and the major free amino acids were Tau, Asp, Glu, Pro, Gly, and Ala. The six amino acids accounted for $70 \%$ of total free amino acids. About $35 \mathrm{mg} / 100 \mathrm{~g}$ of $\beta$-Ala was observed. Cysteine was not found in initial or further fermentation.

After fermentation, total free amino acids showed no remarkable increase in the first two days and then slowly increased to $2,225 \mathrm{mg} / 100 \mathrm{~g}$ in the group with $15 \% \mathrm{NaCl}$ on the 14th day. To explain this phenomenon, the high salt content was considered to be able to inhibit the growth of microorganisms; but it could not completely inhibit the activity of proteolytic enzymes.

On the contrary, total free amino acids rapidly increased and reached their maximum level, 3,103 $\mathrm{mg} / 100 \mathrm{~g}$, in the group without $\mathrm{NaCl}$ on the 7 th day, and then decreased during further oneweek fermentation. In general, the free amino acids and small peptides were the carbon source and nutrients of microorganisms. So, this result could be explained by the fact that the resulting free amino acids and small peptides offered good growth conditions for microorganisms, and that the protein for decomposition was exhausted during fermentation.

Since Tau and $\beta$-Ala were not the consitituent amino acid of protein, there were no remarkable changes to be observed during fermentation either with $(15 \%)$ or without salt. However, Orn was observed to increase to $445 \%$ during fermentation without salt. According to Tokunaga et al.,41) Arg could be degraded by arginase to form Orn. Therefore, a part of the increasing Arg might be transferred into ornithine by arginase existing in oyster paste during fermentation. As for the constituent amino acids of protein, the quantity of each amino acid increased to about $130-340 \%$ after two-week fermentation with $15 \% \mathrm{NaCl}$ (Table 3) and $150-800 \%$ after one-week fermentation without salt (Table 4). Moreover, Murata and Sakaguchit"2) also reported that the Pro of oyster had a decreasing tendency in the whole body and an increasing tendency in the adductor muscle during ice storage. The Pro was also found to have a declining tendency (Table 3 ) and fluctuation (Table 4) during fermentation with $(15 \%)$ and without salt, respectively.

Konosu and Yamaguchi ${ }^{2)}$ reported that Glu, Gly, Ala, Arg, and AMP were the taste components in fish and shellfish. Although free amino acids which have a palatable taste, such as Glu, Gly, and Ala, increased during fermentation, Arg and Val, amino acids which give a bitter taste, also increased in content. However, the total content of the former was higher than that of the latter (Tables 3 and 4).

The dipeptides, glutathionine, balenine, Car, and Ans existing in fish and shellfish muscle have been identified. All of them have been observed in abundance in tuna, skipjack, eel, and shark. Small amounts of Car, Ans, and balenine were also found in crustaceans and mollusks. ${ }^{2)}$ The oyster was shown to have Ans by Lukton and Olcott ${ }^{43)}$ (1958). Athough not all dipeptides were detected at the initial state, nevertheless a small quantity of anserine was found in further fermentation.

\section{References}

1) H. Sekine, S. Tachino, and F. Imamura: Seasonal variation of chemical constituents of oyster. J. Agric. Chem., (Japan) 5, 709-719 (1929).

2) S. Konosu and K. Yamaguchi: The flavor components in fish and shellfish, in "Chemistry and biochemistry of matine products" (ed. by R. E. Martin, G. J. Flick, C. E. Hebard. and D. R. Ward), The AVI Publishing Company. Inc., Westpoint, Connecticut, 1982, pp. 367-404.

3) S. Konosu, K. Yamaguchi, S. Fuke, and T. Shirai: Amino acids and related compounds in the extracts of different parts of the muscle of chum salmon. Nippon Suisan Gakkaishi, 49, 301-304 (1983).

4) T.-K. Chiou, C.-Y. Shiau, and T.-J, Chai: Extract nitrogenous components of cultured milkfish and tilapia. Nippon Suisan Gakkaishi, 56, 1313-1317 (1990).

5) C,-K. Park, T. Matsuj, K. Watanabe, K. Yamaguchi, and S. Konosu: Extractive nitrogenous constituents of two species edible ascidian Styela clava and S. plicata. Nippon Suisan Gakkaishi, 57, 169-174 (1991).

6) K. Endo, M. Hujita, and W. Shimizu: Studies on muscle of aquatic animals XXXIII, Seasonal variation of nitrogenous extractives in squid muscle. Nippon Suisan Gakkaishi, 28, 1099-1103 (1962).

7) K. Endo, Y. Kishimoto, and W. Shimizu: Seasonal variations in chemical constituents of yellowtail muscle-II, Nitrogenous extractives. Nippon Stisan Gakkaishi, 40, 62-72 (1974).

8) K. Watanabe, H. Uehara, M. Sato, and S. Konosu: Seasonal variation of extractive nitrogeneous constituents in the nuscle of the ascidian Halocynthia roretzi. Nippon Suisan Gakkaishi, 51, 1293-1298 (1985).

9) C.-K. Park, T. Matsui, K. Watanabe, K. Yamaguchi, and S. Konosu: Seasonal variation of extractive nitrogenous constituents in ascidian Halocynthia roretzi tissues. Nippon Suisan Gakkaishi, 56, 1319-1330 (1990). 
10) M. Sakaguchi and M. Murata: Seasonal variations of free amino acids in oyster whole body and adductor muscle. Nippon Suisan Gakkaishi, 55, 2037-2041 (1989).

11) C.-K. Park, T. Matsui, K. Watanabe, K. Yamaguchi, and S. Konosu: Regional variation of extractive nitrogenous constituents in the ascidian Halocynthia roretzi muscle. Nippon Suisan Gakkaishi, 57, 731-735 (1991).

12) S. Suyama and S. Konosu: Suisan Shokuhin Gaku (ed. by Suyama and Konosu), Koseisha, Tokyo, 1987, pp. 48-61 (in Japanese)

13) K. Yamaguchi and K. Watanabe: The laste components of extracts, in "Extractive components of fish and shellfish" (ed. by M. Sakaguchi) Suisan Gaku series, 72, Koseisha, Tokyo, 1988, pp. 104-115 (in Japanese).

14) T. Tokunaga, H. Iida, K. Nakamura, K. Sato, S. Ibe, and A. Fujishima: Changes in freshness and taste of horsehair crab meat during iced storage. Bull. Tokai Reg. Fish. Res. Lab., 110, 49-58 (1983).

15) S. Nakamura: Extraction and utilization of oyster extract. New Food Industry. 25, 62-65 (1983) (in Japanese).

16) S. Ichikawa: Research into the high quality of oyster. New Food Industry. 28, 18-23 (1986) (in Japanese).

17) I. Takagi and $\mathrm{K}$. Shimidu: Studies on muscle of aquatic animals-XXXV, Seasonal variation of chemical constituents and extractive nitrogens in some species of shellfish. Nippon Suisan Gakkaishi, 29, 66-70 (1963).

18) G.-J. Sheng, T.-H. Yen, C.-F. Li, and S. P. S. Chi: Manufacture and quality improvement of oyster sauce-I. J. Food Sci. (Taiwan), 15, 27-32 (1988).

19) M. Kunitz: Crystalline soybean trypsin inhibitor. J. Gen. Physiol. 29, 149-154 (1946).

20) W. Rick: Trypsin. In "Methods in Enzymatic Analysis" (ed, by H. U. Bergmeyer), Academic Press, New York and London, 1965, pp. 807-818.

21) K. A. Walsh: Trypsinogens and trypsins of various species. In "Method in Enzymology" (ed. by G. E. Perlmann and L. Lorand), Vol. XIX, Academic Press, New York, 1970, pp. $41-63$.

22) H. U. Bergmeyer, K. Gawehn, and M. Grassl: Enzymes as biochemical reagents. In "Methods of Enzymatic Analysis" (ed. by H. U. Bergmeyer), Vol. I, Academic Press, New York and London, 1974, pp. 436-437.

23) W. Appel: Carboxypeptidases. In "Methods of Enzymatic Analysis" (ed. by H. U. Bergneyer). Vol. II, Academic Press, New York and London, 1974, pp. 989-992.

24) R. Yoshinaka, M. Sato, J. Morishita, Y, Itoh, M. Hujita, and S. Ikeda: Purification and some properties of carboxypeptidase A. Nippon Suisan Gakkaishi, 51, 107-111 (1985).

25) P. Bernfeld: Enzymes of carbohydrate metabolism. In "Methods of Enzymology" (ed. by S. P. Colowick and N. O. Kaplan), Vol. I, Academic Psess, New York, 1955, pp. 149158.

26) L. A. Heppel and R. J. Hilmoe: Enzymes in phosphate metabolism. In "Methods of Enzymology", (ed. by S. P. Colowick and N. O. Kaplan), Vol. II, Academic Press, New York, 1955, pp. 546-550.

27) E. A. Noltmann, C. J. Gubler, and S. A. Kuby: Glucose 6- phosphate dehydrogenase (Zwischenferment). J. Biol. Chem., 236, $1225-1230(1961)$.

28) H. U. Bergmeyer, K. Gawehn, and M. Grassl: Enzymes as biochemical reagents. In "Methods of Enzymatic Analysis" (ed. by H. U. Bergmeyer), Vol, VI, Academic Press, New York and London, 1984, pp. 191-198.

29) R. L. Searcy, S. Hayashi, and J. E. Berk: A modified technique for serum lipase determination. Clin. Biochem., 1, 311-321 (1968).

30) M. Suyama: Determination of non-protein nitrogen extract of tissue, in "Suisan Seibutsu Kagaku Shokuhingaku Jikkensho" (ed. by T. Saito, H. Uchiyama, S. Umemoto, and T. Kawabata). Koseisha, Tokyo, 1974, pp. 1-7 (in Japanese).

31) N. Kondo, K. Imai, B. Isobe, and T. Goto: A low picomole fluorometric detection system for amino acid analysis. Agric. Biol. Chem., 48, 1595-1601 (1984).

32) H. Lowry, N. J. Rosebrough, A. L. Farr, and R. J. Randall: Protein measurement with the Folin phenol reagent. $J$. Biol. Chem. 193, 265-275 (1951).

33) B. F. Cobb III, I. Alaniz, and C. A. Thompson Jr: Biochemical and microbial studies on shrimp-volatile nitrogen and amino nitrogen analysis. $J$. Food $S c i ., 38,431-436$ (1973).

34) R, J. L. Allen: The estimation of phosphorus. Biochem. J., 34, 858-865 (1940).

35) 1. Takagi and $\mathrm{K}$. Shimidu: Studies on muscle of aquatic animals-XXXIV, Constituents and extractive nitrogens in a few species of shellfish. Nippon Suisan Gakkaishi, 28, 11921198 (1962).

36) F. Nagayama: Enzymatic studies on the glycolysis in fish muscle-IIl, Contents of glycolytic intermediates. Nippon Suisan Gakkaishi, 27, 1014-1017 (1961).

37) F. Nagayama: The mechanism of glycogen metabolism and catabolism in vivo. Nippon Suisan Gakkaishi, 32, $188-$ 192 (1966).

38) M. Matsumoto and H. Yamanaka: Changes in contents of glycolytic metabolites and free amino acids in the muscle of kuruma prawn during storage. Nippon Suisan Gakkaishi, 56, 1515-1520 (1990).

39) H. Yamanaka: Changes in polyamines and amino acid in scallop adductor muscle during storage. J. Food Sci., 54, 1133-1135 (1989)

40) F. Nagayama: Studies on the browning of fish flesh-V. Effect of phosphate and other compounds on the browning of glucose-lysine solution. Nippon Suisan Gakkaishi, 27, 34-37 (1961).

41) T. Tokunaga, H. Lida, K. Nakamura, K. Sato, S. Ibe, and A. Fuishima: Changes in freshness and taste of horsehair crab meat during iced storage. Nippon Suisan Gakkaishi, 50, 1875-1878 (1984).

42) M. Murata and M. Sakaguchi: Changes in contents of free anino acids, trimethylamine, and non-protein nitrogen of oyster during ice storage. Nippon Suisan Gakkaishi, 52, 1975-1980 (1986).

43) A. Lukton and H.S. Olcott: Content of free imidazole compounds in the muscle tissue of aquatic animals. Food Res., $23,611-618$ (1958). 